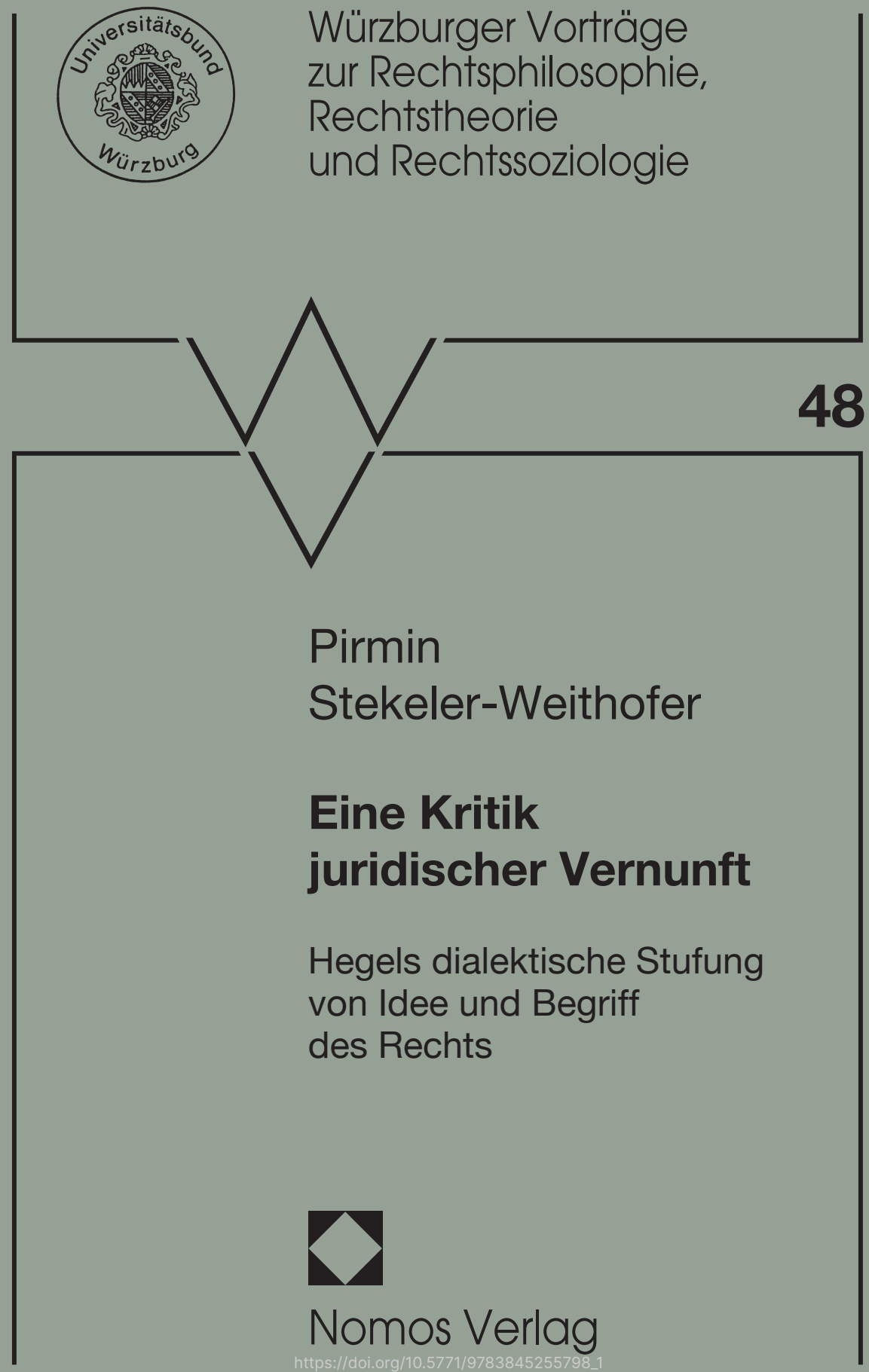


Würzburger Vorträge zur Rechtsphilosophie, Rechtstheorie und Rechtssoziologie

Herausgegeben von Horst Dreier und Dietmar Willoweit

Begründet von Hasso Hofmann, Ulrich Weber ${ }^{\dagger}$ und Edgar Michael Wenz ${ }^{\dagger}$

Heft 48 
Pirmin Stekeler-Weithofer

Eine Kritik juridischer Vernunft

Hegels dialektische Stufung

von Idee und Begriff des Rechts 
Vortrag gehalten am 28. November 2013

Die Deutsche Nationalbibliothek verzeichnet diese Publikation in der Deutschen Nationalbibliografie; detaillierte bibliografische Daten sind im Internet über http://dnb.d-nb.de abrufbar.

ISBN 978-3-8487-1367-7

\section{Auflage 2014}

() Nomos Verlagsgesellschaft, Baden-Baden 2014. Printed in Germany. Alle Rechte, auch die des Nachdrucks von Auszügen, der fotomechanischen Wiedergabe und der Übersetzung, vorbehalten. Gedruckt auf alterungsbeständigem Papier. 


\section{Inhaltsübersicht}

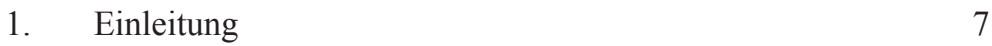

2. Die Idee als Gesamt von Praxisformen 11

3. Das kantische Paradox des unbedingten Lügenverbots 19

4. Das sentimentale Dilemma des Strafens 23

5. Zwei Grundprinzipien des Rechts 25

6. Begriffliche Analyse der Rechtmäßigkeit von Strafe 29

7. Zur Logik der Freiheit 37

8. Zur transzendenten Metaphysik des Naturalismus 45

9. Freie Moral und staatliches Recht 51

10. Zusammenfassender Übergang zur Weltgeschichte 59 
